\title{
Person Observer Role in Organization
}

National Cancer Institute

\section{Source}

National Cancer Institute. Person Observer Role in Organization. NCI Thesaurus. Code C69247.

An indication of the org anizational role of a human observer. 